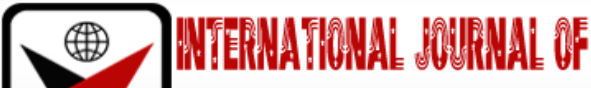

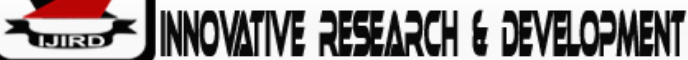

ISSN 2278-0211 (Online)

\section{The Role of Religion in the Spread of Covid-19 in Nigeria}

\author{
Uzodigwe Nnamdi Adolphus \\ Assistant Research Fellow, Department Name: Institute of African Studies, \\ University of Nigeria, Nsukka, Nigeria \\ Akogwu Chukwunonso Joseph \\ Assistant-Lecturer, Department of Political Science, \\ Nnamdi Azikiwe University, Awka, Nigeria \\ Ezeh kelechukwu Dennis \\ Assistant Lecturer, Department of Political Science, \\ Nnamdi Azikiwe University, Awka, Nigeria
}

\begin{abstract}
:
All over the world, corona virus is affecting every sphere of human existence. In Nigeria, the progressing secularization of churches and denominational associations has an impact on individual ethical choices and decisions. In Nigeria, over48 percent of the citizens are affiliated with some religion. Religion has been found to play important role in the spread of the virus in Nigeria. We relied on secondary sources of data. Among other findings of the paper, we discovered that religious beliefs etc. play major roles in the spread of covid-19 in Nigeria.
\end{abstract}

Keywords: Corona virus, pandemic, religion, religious leaders

\section{Introduction}

Corona virus disease also known as COVID-19 is an infectious respiratory disease started around December 2019 in Wuhan, Hubei province of China. It ravaged the world unabated in the year 2020 as the pandemic spread like a wild fire. Consequently, it has a very significant impact on social life, including religious life. As parts of urgent response and efforts to curtail its spread, churches and mosques were locked down in the late March 2020. However, little did the church leaders and other people know that it would take months for churches and other public place of worship to be opened again for large gathering. Its adverse effect restricted and confined Christians to non-municipal religious obligations for the Easter celebrations. Similarly, ban and restrictions were placed on Pilgrimage to Medina/Mecca during the peak of the pandemic. Though individuals celebrated at their different homes but not as a religious group in their different worship centers. In contrast, some religious extremist saw these restrictions as a denial of freedom of worship.

Going from the mode of transmission of COVID-19, religious gatherings and places of worship can be a risk for the contracting the disease as one of the fundamental methods of limiting the expansion of COVID-19 is social distancing. Social distancing has been key in the fight against the rapid spread of COVID-19 with interventions to limit people contact and gatherings introduced in many countries, including the closure of schools, malls, and offices. (Wilder-Smith A, Freedman D0, 2020). Therefore, with clustering congregations and faithful, religious gathering will defy the Social distancing remedy to COVID-19. Accordingly, Wu and McGoogan (2020) observed that though most of the secondary SARS and MERS transmissions took place in hospital settings, thecase ofCOVID-19significant transmission occurs between close contacts of which religious gatherings are typical example.

Similarly, religions in general, and Christian denominations that are based on religious communities are highly and extremely vulnerable as the pandemic poses a greater challenge to the life of these communities. These gatherings often involve dense mixing of many people in a confined space, sometimes over significant periods (Rocklov J, Sjodin H. 2020). The frequency of these gatherings (e.g., in Islam mosques hold five prayers each day) renders them particularly risky during the current pandemic. Recently, numerous COVID-19 cases were linked to places of worship and religious gatherings. For instance, in Malaysia, the Sri Petaling gathering at the end of February 2020 led to 100s of COVID-19 cases across Southeast Asia and was directly linked to nearly 35\% of cases in Malaysia. (Che Mat et al 2020)

Not minding the proliferated secularization in Nigeria, both religion, churches, and denominational associations have an impact on individual ethical choices and business decisions. To some, COVID 19 is a conspiracy hence there are doubts on its reality in Nigeria. While to some others, it is a repercussion for social bedlams caused by individuals. Consequently, such thoughts as indoctrinated to believers wanes the reality of the spread of COVID-19 in Nigeria.

However, In the past religious communities had to seek answers about the spread of pandemics and adapt their religious practices to stemming the tide (Simonsen et al. 2018). For example, the plague that reigned in Europe in fourteenth century, saw Pope Clement VI forbade the practice of self-flagellation to curb the effect. He argued that Jews 
died from the plague as well as Christians, and the pandemic also spreads to regions where they do not live (Poliakov 2003). Again, (Starr 2006 and Gamble 2010) noted that the first half of the 20th century, that was marred with the influenza virus and encephalitis in the United States made churches to close down at that time. In the first decade of the 21st century, there was a swine flu pandemic (Barry 2004; Crosby 2010; Vilensky 2011; Honigsbaum 2020). And currently there is COVID- 19 pandemic, which has made churches and mosque to adjust their obligations and practices to the set-out rules to curb the spread.

Sequel to this, the role of religion in the spread of Covid-19 in Nigeria becomes pertinent as religion has impacted on the behavior and attitudes of individuals. We are not referring to the transmission of religious ideas instead the role of religious practices in spreading the COVID-19 pandemic. Though, little or no report in Nigeria where church gathering has aided in the spread of the disease. The noticeable experience was that members refused to attend services for the fear of getting contacted. Forexample, in Bauchi State, due to COVID-19 the Governor placed major restrictions on markets and places of worship. The residents were banned from conducting the weekly Friday prayers as well as Sunday church services (Haruna, 2020b), same to other states of the federation. In furtherance of religious activities during the COVID 19 pandemic, many churches resulted into live streaming of the normal church services on the cable TV. This means quarantine and a radical change in contacts between people, which goes towards virtualization and online contacts.

However, the potential and perceived threat churches pose to the spread of the pandemic arises from their religious leaders, indoctrinations and beliefs of the followers. Therefore, stern warnings and suggestions (like the use of face masks, hand sanitizers etc) to these church leaders will help to curb and curtail such perceived threat posed by covid19 as individuals tend to adhere fervently to their religious leaders. Some churches and mosques complied, but those that went against this rule were sanctioned, arrested, and duly punished by the task force set to monitor religious activities. There was a case in Bornu State while the restriction order was still in force, three Imams of a weekly Friday mosque went ahead and encouraged worshiper to congregate for the Friday service, the consequence was that they were arrested and sanctioned (Haruna 2020a). In Lagos State, during a church service, the pastor of the church and four others were arrested for violating the COVID - 19 regulation (Alabi, 2020). Other, examples where religion exacerbated the spread of COVID 19 is in South Korea.

As of the end the first week of March 2020, almost two-thirds of coronavirus infections (nearly 5,000 cases) were traced back to "Patient 31," an individual who worshipped at Shincheonji Church of Jesus in Daegu. (Rashid 2020, New York times). Another example, include Rev. Tony Spell is pastor of Life Tabernacle Church, a Oneness Pentecostal congregation in Baton Rouge, USA. Explaining his defiance of the Louisiana Governor's order banning meetings of more than fifty people, Rev. Spell was quoted as saying, "It's not a concern.

The virus, we believe, is politically motivated. We hold our religious rights dear and we are going to assemble no matter what someone says."(Wisely et al, 2020). Collective worship is an effective mechanism for accelerating its spread. Though recalcitrant religious congregations are accelerating viral transmission, it is notable that most religious groups are innovating in response to opposing demands of collective worship and social distancing. For example, religious communities all over the world are conducting online services, stretching the world's data bandwidth at certain times of the week to stream live videos of suitably modified rituals, sermons, and prayers.

\section{Statement of the Problem}

Against the backdrop that the lockdown of churches and other public places as witnessed in Nigeria prevented pastors from performing their pastoral ministry in the traditional ways through physical contacts, churches found other means of holding their church activities through virtualization and online platforms. However, with the ease of lock down and reopening of churches, this paper is an attempt to find out the role of religion in the spread of COVID -19 focused on the following two research questions:

- Whether the responses by different Churches from various denominations against the COVID-19 pandemic have significant effect on the spread of corona virus in Nigeria?

- To ascertain whether non-municipal religious obligations were implicated in the spread of COVID-19 in Nigeria?

\section{Framework}

The conceptual framework of this study is based on some excerpts of Ağllkaya-Şahin (2016)'s "Pastoral Care in Christian Tradition". The word "pastoral" is derived from the concept of shepherding as adopted by the Early Church. This concept "Pastoral care" justifies such qualities like consolation, resolution, counseling, and healing. It can be described as the art of helping "in improving people's religious and ethical development. Hence because of the effect of the pandemic such qualities as found in pastoral care are altered. Therefore, online streaming of church services which is an alternative do not really make some religious fanatics feels the essence of Pastoral care.

\section{Conceptualization of Terms}

\subsection{Pandemic}

The term 'pandemic' means a serious infectious disease that spreads rapidly between people and occurs at the same time not only in one country but around the world (Hawker 2005; Crowther 1998). Pandemic. Its described as sudden emergence and global spread of disease around the world that is beyond health emergency and calls for immediate action to resolve its adverse effect. 


\subsection{Religion}

The term religion has numerous definitions from different background by different scholars. Durkheim, for instance, defined a religion as "a unified system of beliefs and practices relative to sacred things ... beliefs and practices that unite into one single moral community called a Church, all those who adhere to them" (Durkheim 1915). Inherent in the concept of religion is the system of beliefs and practices.

\subsection{COVID-19}

Coronavirus disease 2019 (COVID-19) is defined as an illness caused by a novel coronavirus now called severe acute respiratory syndrome coronavirus 2 (SARS-CoV-2; formerly called 2019-nCoV), which was first identified amid an outbreak of respiratory illness cases in Wuhan City, Hubei Province, China (CDC 2019).

\subsection{Religious Leaders}

Religious leader(s) is a person who is recognized within a particular religion as having authority within that body. In Nigeria context we have the Imams, Bishops, GOs (General over seers), Apostles etc.

\section{Literature Review}

\subsection{Meaning, Origin and Spread of Covid-19 Pandemic}

The COVID-19 pandemic is considered the one among the biggest pandemics to humans (Du Toit, 2020). Starting from Wuhan City, Hubei Province of China (Original epicenter of COVID-19) and spreading around the globe in less than 3 months (Anadolu Agency 2020).

The corona virus disease (COVID-19) is a highly transmittable and pathogenic viral infection caused by severe acute respiratory syndrome coronavirus 2 (SARS-CoV-2), which emerged in Wuhan, China and spread around the world (Shereen, Khan, Siddique and Kazmi, 2020). Coronaviruses belong to the Coronaviridae family in the Nidovirales order. Corona represents crown-like spikes on the outer surface of the virus; thus, it was named as a coronavirus. Coronaviruses are minute in size (65-125 $\mathrm{nm}$ in diameter) and contain a single-stranded RNA as a nucleic material, size ranging from 26 to $32 \mathrm{kbs}$ in length (Shereen et al, 2020).

By the end of 2019, WHO was informed by the Chinese government about several cases of pneumonia with unfamiliar etiology ( $\mathrm{Li}, \mathrm{Guan}, \mathrm{Wu}, 2020$ ). The outbreak was initiated from the Hunan seafood market in Wuhan city of China and rapidly infected more than 50 peoples. The live animals are frequently sold at the Hunan sea-food market such as bats, frogs, snakes, birds, marmots and rabbits (Wang, Horby, Hayden, Goa, 2020). On 12 January 2020, the National Health Commission of China released further details about the epidemic, suggested viral pneumonia (Wang, et al 2020). From the sequence-based analysis of isolates from the patients, the virus was identified as a novel coronavirus.

Moreover, the genetic sequence was also provided for the diagnosis of viral infection (Phan et al, 2020). Initially, it was suggested that the patients infected with Wuhan coronavirus induced pneumonia in China may have visited the seafood market where live animals were sold or may have used infected animals or birds as a source of food (Parry, 2020). However, further investigations revealed that some individuals contracted the infection even with no record of visiting the seafood market. These observations indicated a human to the human spreading capability of this virus, which was subsequently reported in more than 100 countries in the world (Riou et al, 2020). The human to the human spreading of the virus occurs due to close contact with an infected person, exposed to coughing, sneezing, respiratory droplets or aerosols. These aerosols can penetrate the human body (lungs) via inhaling through the nose or mouth (Li et al, 2020).

The most common symptoms of COVID-19 are fever, dry cough, and tiredness. Other symptoms that are less common and may affect some patients include aches and pains, nasal congestion, headache, conjunctivitis, sore throat, diarrhea, loss of taste or smell or a rash on skin or discoloration of fingers or toes. These symptoms are usually mild and begin gradually. Some people become infected but only have very mild symptoms (WHO, 2020).People can catch COVID-19 from others who have the virus. The disease spreads primarily from person to person through small droplets from the nose or mouth, which are expelled when a person with COVID-19 coughs, sneezes, or speaks (WHO, 2020).

However, these droplets are relatively heavy, do not travel far and quickly sink to the ground. People can catch COVID-19 if they breathe in these droplets from a person infected with the virus (WHO, 2020). These droplets can land on objects and surfaces around the person such as tables, doorknobs and handrails. People can become infected by touching these objects or surfaces, then touching their eyes, nose or mouth (WHO, 2020). The disease spreads from person to person through infected air droplets that are projected during sneezing or coughing. It can also be transmitted when humans have contact with hands or surfaces that contain the virus and touch their eyes, nose, or mouth with the contaminated hands (Africa CDC, 2020).

\section{Religion and Impact on the Spread of Covid 19 around the World}

Religion has impacted and will continue to impact the COVID-19 response in myriad ways. It has spread and will continue to spread the disease through continued religious gatherings that ignore public health advice (Blevins, 2020). The outbreak of Covid19 disease is not the problem, but the kind of attitudes and behaviors exhibited by leaders especially the religious leaders (RLs) during the period (Adetunji, Funke and Oyekan, 2020). Religious Leaders' attitudes definitely had serious effects on the disposition of believers during and after COVID-19, and eventually the practicability of the various measures put in place to solve the problem (Adetunji et al, 2020).

Sahin et al. (2020) noted that Severe Acute Respiratory Syndrome (SARS) such as COVID-19 thrives well where there is large-scale travel traffic as was the case of 3.11 billion people who travelled to Wuhan for the Spring Festival. 
Religious gatherings across religions of the world are also known for large-scale movement or crowding together of worshippers or adherents". Religion is a potent, long-standing, and pervasive social force. The social power it generates can be used in helpful ways to slow the spread of COVID-19 or in harmful ways that hasten the spread of the virus. Religious gatherings have been key drivers of the spread of the disease (Blevins, 2020).

Infections tied to services held by a Christian group in South Korea in early February formed the epicenter of the outbreak there (Blevins, 2020). As of the end the first week of March 2020, almost two-thirds of coronavirus infections (nearly 5,000 cases) were traced back to "Patient 31," an individual who worshipped at Shincheonji Church of Jesus in Daegu in South Korea (Wildman, Bulbuli, Sosis and Schjoedt, 2020). The church had insisted on in-person meetings, banning health masks, praying while touching others, and refusing to turn over its membership list to health officials. Routinely accused by mainline Protestant Christian denominations of being a secretive sect, now it is being blamed for contributing to the local epidemic of COVID-19. It didn't help that the church's leader, 88-year old Mr. Lee Man-hee, explained the epidemic as the Evil One fighting back against the rapid growth of the church he founded. Koreans are outraged and urging the government to prosecute Mr. Lee for murder due to gross willful negligence. The $27 \%$ of Koreans who identify as Christian are distancing themselves from the Shincheonji Church of Jesus as fast as humanly possible (Wildman et al, 2020). Infections that occurred during a four-day pilgrimage to Malaysia in late-February by 16,000 Muslim faithful are believed to have spread the virus to six other countries (Blevins, 2020).

Observing Trinidad in the West Indies, a young man was confronting a conflict between government health officials and some pastors of local churches. The health officials were pleading with stores and places of worship to cease gatherings until further notice. Meanwhile, these pastors were continuing to hold in-person services on the basis that a failure to attend worship in person is evidence of a lack of faith-arguably bullying church members to show up against their better judgment (Wildman et al, 2020).

Another example is Rev. Tony Spell, a pastor of Life Tabernacle Church, a Oneness Pentecostal congregation in Baton Rouge, USA. Explaining his defiance of the Louisiana Governor's order banning meetings of more than fifty people, Rev. Spell was quoted as saying, "It's not a concern. ... The virus, we believe, is politically motivated. We hold our religious rights and we are going to assemble no matter what someone says." (Wildman et al, 2020). About three hundred people gathered on the Tuesday after the ban and over a thousand on the following Sunday. Rev. Spell is handing out anointed handkerchiefs, preaching against fear, and telling his people, who are mostly bussed in from poor regions all around the city, that this is an extreme test of faithfulness brought on by the spirit of the antichrist (Wildman et al, 2020).

Iran was one of the worst-hit countries in the current pandemic. It is a prime example of how Religious Congregation (RC) can impact disease transmission. The first COVID-19 deaths were reported from the Shiite city of Qom on February 19, 2020. The disease had apparently started two to three weeks earlier. The Head of the main shrine in Qom appealed to the pilgrims to keep coming to the shrine and called it a place of healing. This apparently led to the unabated spread of the infection, not only within Iran, but around a dozen neighboring countries (Wright, 2020).

Three Tablighi Jamaat meetings in Malaysia, Pakistan, and India became COVID-19 hotspots. The first was from the Tablighi assembling in Malaysia from February 27 to March 3. As many as 1,545 COVID-19 cases in Malaysia were linked to the assembly of Tablighi Jamaat in Kuala Lumpur (Daim, 2020). This apparently acted as a source of the infection for the subsequent two gatherings in Pakistan and India, because the infected Malaysians attended those assemblies. Around 150,000 preachers, mostly from Pakistan but some from other Muslim countries, gathered for a Tablighi Ijtema, a congregation of the preachers, on March 12, 2020, in the eastern Pakistani city of Lahore. This gathering is described as a transmission hub in Pakistan. The gathering was canceled at the last moment at the behest of the Pakistani Government, but by that time, preachers had already assembled in large numbers. The problem could further explode in the coming weeks (Ur-Rahman et al., 2020).

Tablighi Markaz in the Nizamuddin area of Delhi, the Capital of India, is the global headquarters of the Tablighi Jamaat. Preachers from India and abroad visit this place for deliberations and to learn the Islamic texts. On March 30, 2020, 300 of its members were isolated and tested for COVID-19, after it became known that a gathering of the preachers had included Malaysians and Indonesians. By April 4, 2020, 1023 people linked to this Tablighi Jamaat congregation tested positive across the country (Kumar, 2020). By this time, several attendees of the congregation had already dispersed before the cluster was identified. Apparently, many of them have carried the virus to their native states, posing the threat of broader community spread (Daim, 2020).

Though no ethnic categorization of Britain's COVID-19 patients could be found, the independent newspaper reported that Muslims have severely faced the wrath of the pandemic. Large extended families, handshaking, and mosque attendance were cited as the possible reasons (Hussain, 2020).

\section{The Role of Religion and Religious Conspiracy Theories in the Spread of Covid19 in Nigeria}

There has been resistance from religious leaders on a continent where millions of people frequent churches and mosques regularly, with several ignoring the call for social distancing (Soto 2020).Nigerians like to say that they are the world's most religious people and the happiest, despite their low standing on most of the standard indices of development (John Campbell, 2020). In Nigeria, people have a strong attachment to religion (Olukoya and Mohammed, 2020).

Several imams have been suspended for violating state-imposed measures to slow down the spread of COVID19 in a country whose health system risks being overwhelmed by the pandemic (Olukoya and Mohammed, 2020). Muslims also feel threatened by perceived attempts by secular powers to regulate their religion. Some even think that this is a conspiracy to prevent Muslims from praying, and that there is no such thing as a corona virus (Olukoya and Mohammed, 2020). When it comes to spurious information and the coronavirus, it has been an open season with some 
Nigerian evangelical pastors. As purveyors of disinformation, several pastors have pushed back against government lockdowns that would impact church closures (Egbunike, 2020).

Bishop Oyedepo called the shutdown of churches at the peak of the epidemic "an attempt to cripple Christianity." Going further, he said, "whoever stops the church from fellowshipping is out to destroy what God is building. There must be a devil behind it. It is not virus, it is demon, there is a demon at work behind the scene, I told you in the morning I can smell a rat." (Olukoya and Mohammed, 2020).

Similarly, Pastor Chris Oyakhilome linked the virus with 5G technology (Orjinmo, 2020). Chris Oyakhilome has publicly stated that the introduction of 5G technology was responsible for the outbreak of the coronavirus pandemic, and the administration of a COVID-19 vaccine will be used as a ruse to enthrone a new world order led by the anti-Christ. He believes that wearing masks is politics rather than science (Vanguard 2020).

In a similar vein, Prophet TB Joshua claimed to be divinely inspired and predicted that the coronavirus pandemic would be over by 27 March, several days before a lockdown was imposed on the states of Lagos, Ogun and the capital, Abuja (Orjinmo, 2020).From the available literature reviewed, public utterances, beliefs and teachings of several prominent religious leaders in Nigeria right from the onset of the outbreak of corona virus overseas, greatly influenced many religious fanatical Nigerians into violating Federal Government's directives geared towards curtailing the spread of the highly contagious virus within and around the country. Based on the foregoing, the paper investigated how various religious ideas, beliefs, directives, practices, etc. showcased by many Nigerians since the outbreak of the virus, helped in its eventual wide spread around the country.

\section{Conclusions and Recommendations}

Despite the response from churches (use of online platforms) and the ease/ opening of churches and mosques in Nigeria, religion holds a strong means of either exacerbating the spread of the pandemic or curbing it. The study investigated the impact of religion in the spread of COVID-19 pandemic in Nigeria. Specifically, it questioned whether the actions by different denominational churches and mosques aided the spread of the Virus and whether the non-municipal religious obligations by Nigerians such as celebrating Easter and Salah at homes, private and family prayers and gatherings are implicated in their religious belief. These objectives informed the study and hypotheses.

After a thorough analysis of the generated data, the study found out that;

- Though the lock down of churches and ban on all religious gatherings did not to a significant extent escalate the spread of COVID-19 in Nigeria. Rather the recalcitrant religious leaders were shunned and sanctioned. Again, culling from the response of churches and some denominational churches, utterances and opinions of their religious leaders are of utmost important as it influences and guides the attitudes and behaviours of their followers. Therefore, with the ease of lockdown and opening of churches, religious leaders have major roles to play in curbing the spread of the pandemic.

- Again, although the response and resorting to online streaming of church services is a welcomed development, non-municipal religious obligations by individuals as depicted in private and family prayers, and other religious activities discretely were manifestations of religious belief of Nigerians. Hence religion holds essential role to play in the spread of the virus. Again, the anxiety on the effect of covid-19 as seen in other developed countries where such religion is being practiced e.g. Italy for Christians put in a drift to self-preservation than adherence to religious practices.

Against this backdrop, the study hence advocates the following recommendations in other to remedy the noted maladies;

- Religious leaders should be frequently reminded of the adverse effects of COVID-19, therefore, such preventive mechanisms like social distancing, face mask, washing facilities should always be available.

- On the aspect of the individual, non-municipal religious obligations are also important to strengthen one's belief in his/her religion. Therefore, frequent adherence to church public activities should be exempted.

\section{References}

i. ACDCP. Africa Centers for Disease Control and Prevention, "Coronavirus Disease 2019 (COVID-19)," https://africacdc.org/covid-19/.

ii. Adetunji, A., Funke, E., and Oyekan, F. (2020). Organization Behavior: The Attitude of Religious Leaders in the Phase of Pandemic. International Journal of Psychosocial Rehabilitation 24(10):2993- 3003.

iii. Anadolu Agency. COVID-19 outbreak similar to previous pandemics. [cited 2020 August 4]. Available from: https://www.aa.com.tr/en/economy/covid-19- outbreak-similar-to-previous-pandemics/1777389

iv. Blevins, J. (2020) 'COVID-19, Religion and the Importance of Effective Leadership'. LSE Religion Scholars Network Day Conference.

v. Che Mat NF, Edinur HA, Abdul Razab MKA, and Safuan S. (2020) 'A single mass gathering resulted in massive transmission of COVID-19 infections in Malaysia with further international spread'. Journal of Travel Medicine 2020

vi. Egbunike, N (2020). (2020). 'Nigerian Pastors spread COVID 19 conspiracies and misinformation'. Vanguard Newspaper, May 15.

vii. https://www.change.org/p/john-bel-edwards-we-demand-the-prosecution-of-pastor-spell-of-lifetabernaclechurch.

viii. https://www.msn.com/en-us/news/us/pastor-defies-coronavirus-order-draws-over-1k-people-to-services/ ar-BB11HwQ3. 116 EDITORIAL

ix. https://www.nytimes.com/2020/03/09/opinion/coronavirus-south-korea-church.html. 
x. https://www.nytimes.com/2020/03/26/world/asia/pakistan-coronavirus-tablighi-jamaat.html [Accessed 8 September 2020].

xi. John Campbell (2020). 'Principal Nigerian Religious Leaders Largely in Lockstep with Government on Lockdowns'. Council on Foreign Relations.

xii. Li, Q., Guan X, Wu, P., Wang X., Zhou L., Tong Y. (2020). 'Early transmission dynamics in Wuhan, China, of novel coronavirus pneumonia'. $N$ EnglJ.

xiii. Olukoya, S., and Mohammed. Z. (2020). 'Nigerian religious leaders demand lifting of COVID-19 lockdown'. DW Unbiased journalism for free minds.

xiv. Orjinmo, N. (2020). 'Coronavirus: Nigeria's mega churches adjust to empty auditoriums. BBC News Lagos, 8 April.

xv. Oyelola A. Adegboye, Adeshina I. Adekunle, and Ezra Gayawan (2020). "Early Transmission Dynamics of Novel Coronavirus (COVID-19) in Nigeria". International Journal of Environmental Research and Public Health. 2020, 17,3054

xvi. Parry J. (2020). 'China coronavirus cases surge as official admits human to human transmission'. British Medical Journal Publishing Groups.

xvii. Peterson Ozili (2020). "Covid-19 pandemic and economic crisis: The Nigerian experience and structural causes". International Journal of Sociology and Social Policy, 2020. Retrieved June 7, 2020 from http://dx.doi.org/10.2139/ssrn.3567419, 2.

xviii. Phan LT, Nguyen TV, Luong QC, Nguyen HT (2020). 'Importation and human-to-human transmission of a novel coronavirus in Vietnam'. N Engl J Med.

xix. Riou J, Althaus CL. (2020). 'Pattern of early human-to-human transmission of Wuhan 2019 novel coronavirus (2019-nCov), December 2019 to January 2020'. Euro-surveillance. 2020; 25 (4).

xx. Rocklov J, and Sjodin H (2020). 'High population densities catalyze the spread of COVID19'. J Travel Med 2020.

xxi. Saber Yezli and Anas Khan (2020) 'COVID-19 pandemic: It is time to temporarily close places of worship and to suspend religious gatherings' Dr. Global Centre for Mass Gatherings Medicine Public Health Directorate Ministry of Health Riyadh Saudi Arabia

xxii. Sahin, A. R., Erdogan, A., MutluAgaoglu, P., Dineri, Y., Cakirci, A. Y., \&Senel, M. E. (2020). 'Religion and Spread of Covid19 in Asia'. The New York Times March.

xxiii. Shereen, M.A., Khan, S., Siddique, R., Kazmi, A. 2020. 'Covid-19 Infection, Origin, transmission and characteristics of human coronavirus'. Journal of Advanced Research, March 2020.

xxiv. Soto, A. (2020).' Nigeria Arrests Pastor, Ghana Halts Funerals to Curb Virus'. BLOOMBERG March 22 ${ }^{\text {nd }}$.

xxv. Sulkowski and Grzegorz (2020) 'Impact of COVID-19 Pandemic on Organization of Religious Behaviour in Different Christian Denominations in Poland' MPDI.

xxvi. The ethical pattern is laid out in Jeffrey Stout's unpublished Gifford Lectures, "Religion Unbound: Ideals and Powers from Cicero to King," available online at https://www.giffordlectures.org/lecturers/jeffrey-stout.

xxvii. Tips for Social Distancing, Quarantine, And Isolation During an Infectious Disease Outbreak". Retrieved March 28, 2020 from https://www.samhsa.gov/sites/default/files/tips-social-distancing-quarantine-isolation031620.pdf, p. 1.

xxviii. Wang, C. Horby, P.W. Hayden FG, Gao GF. (2020). 'A novel coronavirus outbreak of global health concern'. The Lancet.

xxix. Wesley J. Wildman, Joseph Bulbulia, Richard Sosis\&UffeSchjoedt (2020) 'Religion and the COVID-19 pandemic; Religion, Brain \& Behavior, 10:2, 115-117, DOI: 10.1080/2153599X.2020.1749339

xxx. WHO, Regional Office for Africa (2020) COVID-19: External Situation Report 9.

xxxi. Wilder-Smith A and Freedman DO (2020) 'Isolation, quarantine, social distancing and community containment: pivotal role for old-style public health measures in the novel coronavirus (2019-nCoV) outbreak'. J Travel Med 2020; 27(2).

xxxii. Wildman, w.J., Bulbulia, J., Sosis, R., and Schjoedt, U. (2020). 'Religion and the Covid-19 Pandemic'. Journal of Religion, Brain and Behaviour Vol 10.

xxxiii. Wright, R. (2020). 'How Iran became a new epicenter of the coronavirus outbreak' The New Yorker February 28.

xxxiv. ZuhâlAğılkaya-Şahin (2016). "Theoretical Foundations of Pastoral Care in Christian Tradition". Spiritual Psychology and Counseling, 1, 65-74. Retrieved May 27, 2020 from http://dx.doi.org/10.12738/spc.2016.1.0002. 